\title{
THE CONCEPT OF MICROPROCESSOR REGISTRATION SYSTEM OF ENERGY CONSUMPTION OF AN UNDERWATER VEHICLE
}

\section{Tomasz Leszczyński}

Polish Naval Academy, Faculty of Mechanical and Electrical Engineering, Śmidowicza 69 Str., 81-127 Gdynia, Poland; e-mail: t.leszczynski@amw.gdynia.pl

\begin{abstract}
The article, on the basis of the underwater vehicle 'Głuptak' intended to combat naval mines, outlines the general concept of the microprocessor system of registration of change of electricity stored in batteries for the underwater vehicle at the implementation time of the set task. Registration system the amount of energy allows you to optimize the implementation of the working time of the underwater vehicle drive system in conditions of interference type underwater sea current.
\end{abstract}

Key words:

underwater vehicle, measurement of energy consumption, location of the vehicle.

Research article

(C) 2018 Tomasz Leszczyński This is an open access article licensed under the Creative Commons Attribution-NonCommercial-NoDerivatives 4.0 license (http://creativecommons.org/licenses/by-nc-nd/4.0/) 


\section{INTRODUCTION}

An underwater vehicle implementing a placed task, e.g. to combat naval mines requires adequate energy resources to ensure maneuvering in accordance with the developed scenario. In the case of external interferences on the vehicle it might turn out that energy resources do not provide the implementation of the set task. Application of microprocessor control of power consumption by appliances installed on the vehicle allows to optimize the route of the vehicle depending on the amount of available energy and the amount of external interferences.

During the execution of a task distribution of interferences is not uniform. By analyzing the data contained in the model of the sea currents HIROMB of the Institute of Meteorology and Water Management [9], it can be observed that the direction and speed of the current is fixed on limited areas. The reallocation of the object with a few dozen meters causes that the vehicle will be in an area with other parameters of current having impact on it. During the execution of the set task an underwater vehicle must steer clear of objects of different immersion and different nature. This can cause an increased demand for the energy required to produce by vehicle's propeller optimal values of forces and moments to ensure its movement along the designated route.

The next factor affecting the working time of the underwater vehicle is the water temperature in its surrounding. It results from the HIROMB [9] that the amplitude of temperature changes of water depends largely on the type of currents present in the vehicle surrounding. In the summer period the local temperature change may reach up to about $10^{\circ} \mathrm{C}$. Transition of the vehicle from an area of higher temperature to an area of lower temperature adversely affects the performance of accumulator battery installed on the vehicle, which in turn may lead to the risk of execution the set task.

\section{THE STRUCTURE OF THE MEASUREMENT SYSTEM IN THE UNDERWATER VEHICLE}

A self-propelled charge to combat naval mines 'Głuptak' is a remotely controlled underwater vehicle of a torpedo like hull shape designed in the Department of Ships Design and Subsea Robotics of the Gdańsk University of Technology. This is a disposable vehicle, powered from its own on-board power source and controlled remotely via cable line by the operator. 
Due to its destiny the 'Głuptak; vehicle is equipped with the following devices to give feedback about the temporary position and orientation of the vehicle [7]:

- magnetic compass Honeywell HMR3000 with the body roll (swinging side and wagging) and trims gauges;

- echo sounder (product of PG) - measurement of the distance from the bottom the range $0-50 \mathrm{~m}$, resolution $1 \mathrm{~cm}$, measuring frequency $10 \mathrm{~Hz}$;

- pressure gauge - depth gauge-Keller PA 33XH, range 0-30 bar;

- vision camera.

Based on the information from the above mentioned sensors the operator controls the course and immersion of the vehicle.

In [4] the structure of automatic control of the movement of the vehicle from a specified initial state to desired end state in different meteorological conditions prevailing in the area of the moving vehicle has been shown. The simulation tests of system work carried out on the basis of the model presented in figure 1 . In the course of the simulation the study of the impact on vehicle of the parameter of the marine current parameter changes assuming static obstacles on the route of movement of the vehicle.

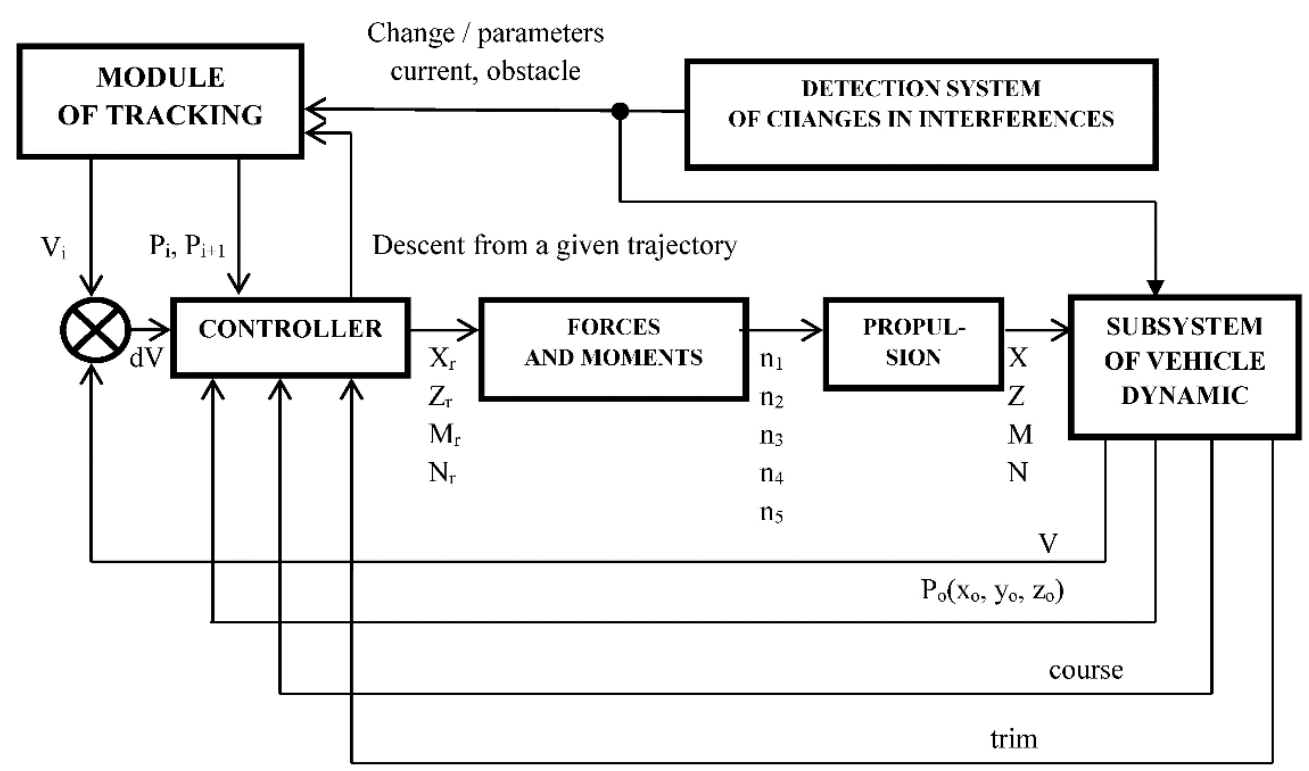

Fig. 1. Simulation model of the object with the road module on which the vehicle is traveling and detection of changes of interferences in the environment: $V_{i}$ - nominal speed of the vehicle on the step $i, V$ - current vehicle speed; $d V$ - speed error; $P_{i} P_{i+1}$ - boundaries of the step and road; $P_{o}$ - vehicle position; $X_{r}, Z_{r}, M_{r}, N_{r}$ - asked forces and moments of the controller; $n_{1}-n_{5}-$ asked revolutions of propellers; $X, Z, M, N$ - forces and moments generated by propellers [own study] 
Some sample from vehicle simulation are presented in figures 2 and 3. From the drawings follows that the accuracy of keeping the vehicle on the route is also affected by the instruments, from which information about the position and course of the vehicle is acquired.

The structure of the measuring system of the underwater vehicle used by it constructors does not give the possibility of the precise determination of the position of the vehicle. Currently an error determining the position of the vehicle by the inertial navigation system is approximately $1.5 \mathrm{~m}$. The problem of increasing the accuracy of determine the position of the vehicle can be solved, e.g. through the replacement of current instruments with instruments of a higher accuracy.

The more difficult to solve is the problem of determining the quantities of energy that remained in the cells of the underwater vehicle battery at the given moment of time, i.e. uniquely determine the feasibility of the tasks in the current conditions. On the solving of the problem mentioned above, a big impact have the conditions under which battery cells installed on the vehicle work.

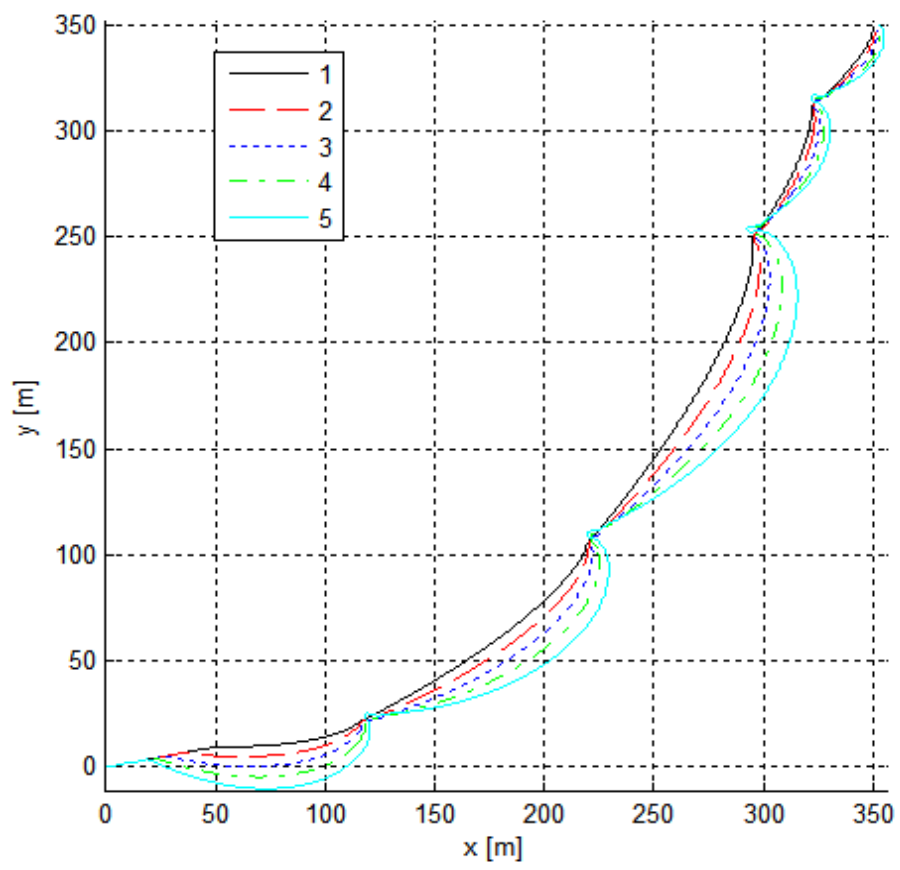

Fig. 2. Vehicle trajectories - various sea current speed value, vehicle speed id $2.0 \mathrm{~m} / \mathrm{s}$, sea current from the direction $90^{\circ}$ for: $1-0.4 \mathrm{~m} / \mathrm{s}, 2-0.6 \mathrm{~m} / \mathrm{s}, 3-0.8 \mathrm{~m} / \mathrm{s}, 4-1.0 \mathrm{~m} / \mathrm{s}$, $5-1.2 \mathrm{~m} / \mathrm{s}[4]$ 


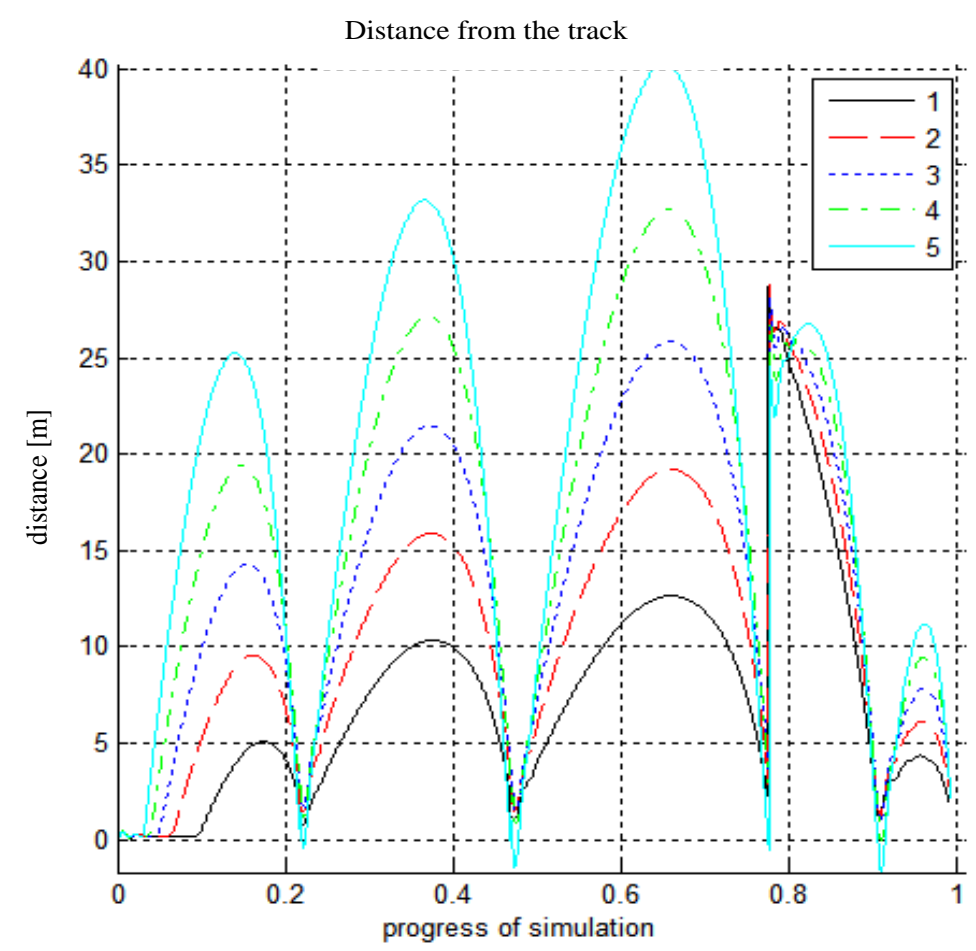

Fig. 3. Distance of vehicle from the user with-various sea current speed magnitudes, vehicle speed id $2.0 \mathrm{~m} / \mathrm{s}$, sea current from the direction $90^{\circ}$ for: $1-0.4 \mathrm{~m} / \mathrm{s}, 2-6 \mathrm{~m} / \mathrm{s}, 3-0.8 \mathrm{~m} / \mathrm{s}$, $4-1.0 \mathrm{~m} / \mathrm{s}, 5-1.2 \mathrm{~m} / \mathrm{s}[4]$

\section{THE OPERATION OF BATTERY CELLS OF THE UNDERWATER VEHICLE}

To power the underwater vehicle 'Głuptak' the batteries Headway HW-38140S are used, which characteristics describing their action are presented in figures 3-6 [13].

From the presented characteristics it can be seen that for the relevant cells, in addition to the power charged from the battery, also their temperature during operation of the vehicle must be taken into account due to its impact on the capacity of the battery.

Assuming that the amount of available energy should be a function whose components are: the life curve of battery pack (fig. 6), a family of battery discharge characteristics for various values of currents (fig. 5) and family characteristics of discharge for various temperatures (fig. 6), it is possible to more accurately estimate the current battery energy resources based on the battery thermal model (fig. 7), whose proposal is contained in $[5,6]$.

1 (212) 2018 


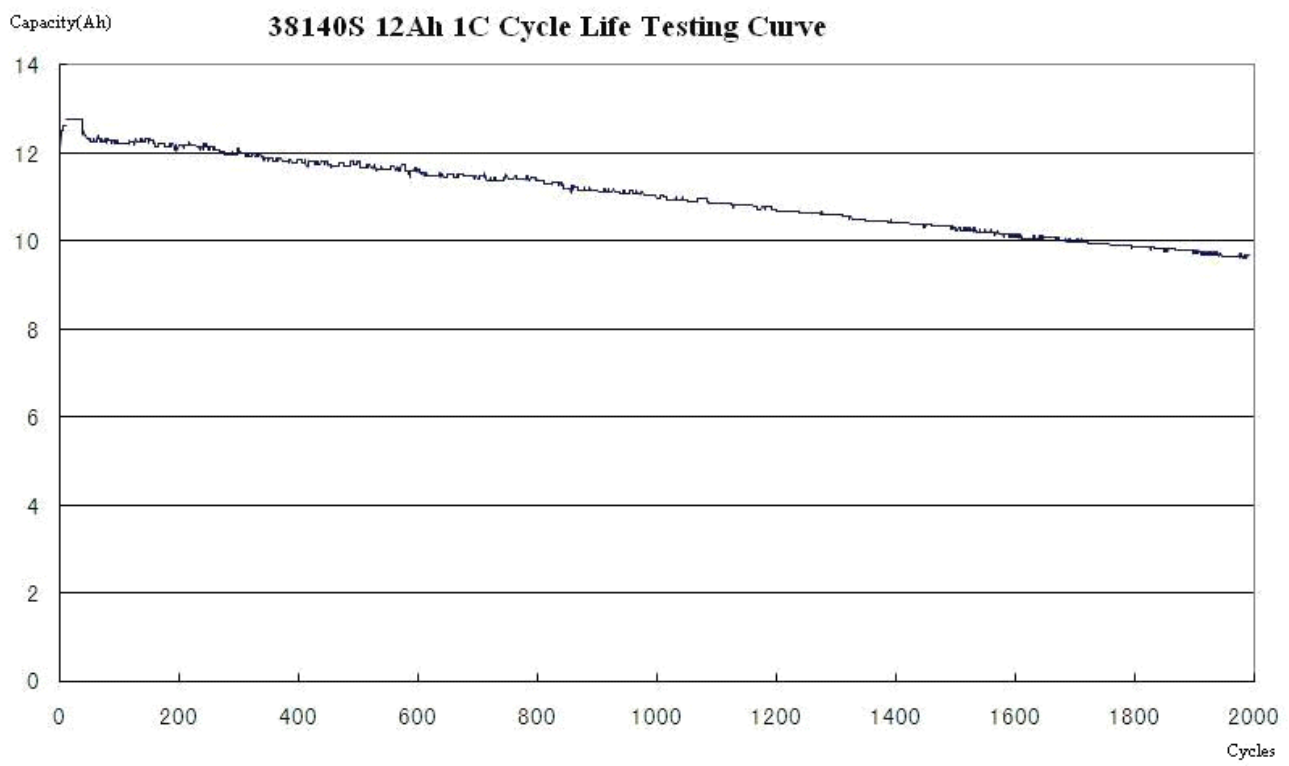

Fig. 4. Life-cycle curve made available by the manufacturer for the discharge current equal $1 \mathrm{~A}[13]$

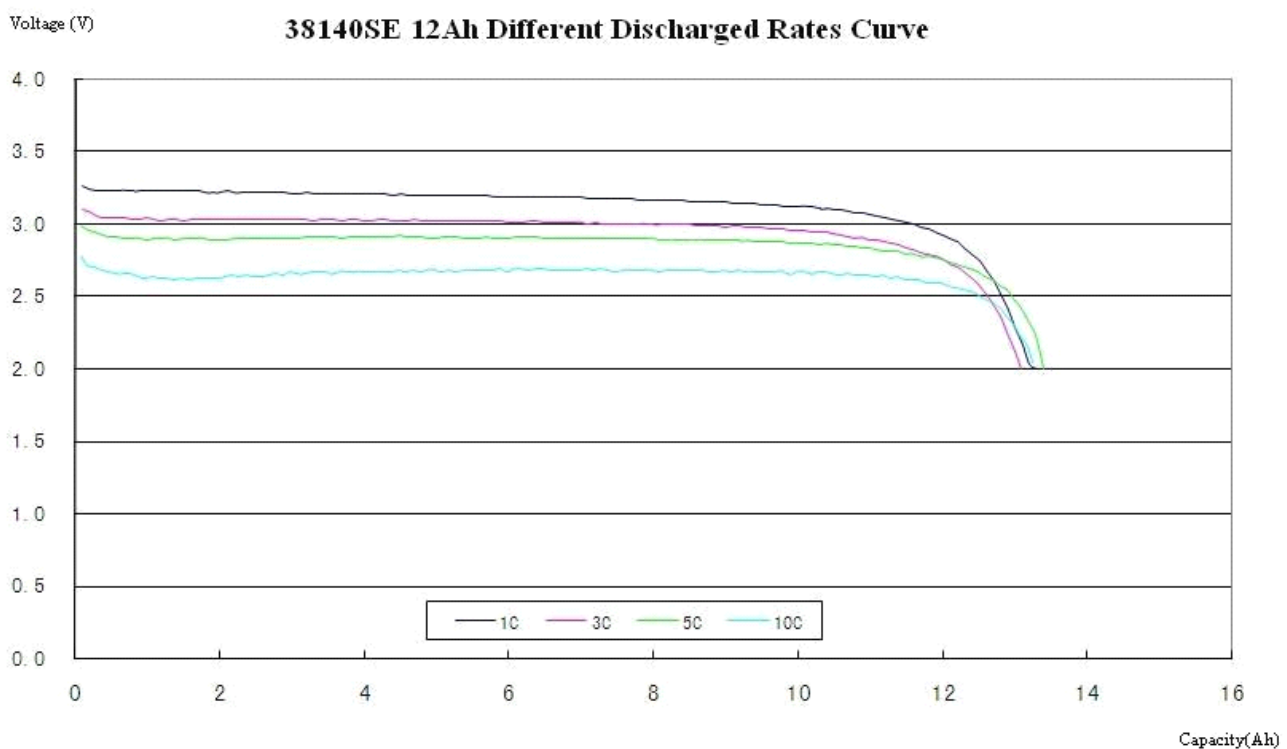

Fig. 5. The characteristics of the discharge of battery for various values of the discharge currents: $1 \mathrm{~A}, 3 \mathrm{~A}, 5 \mathrm{~A}$ and $10 \mathrm{~A}[13]$ 


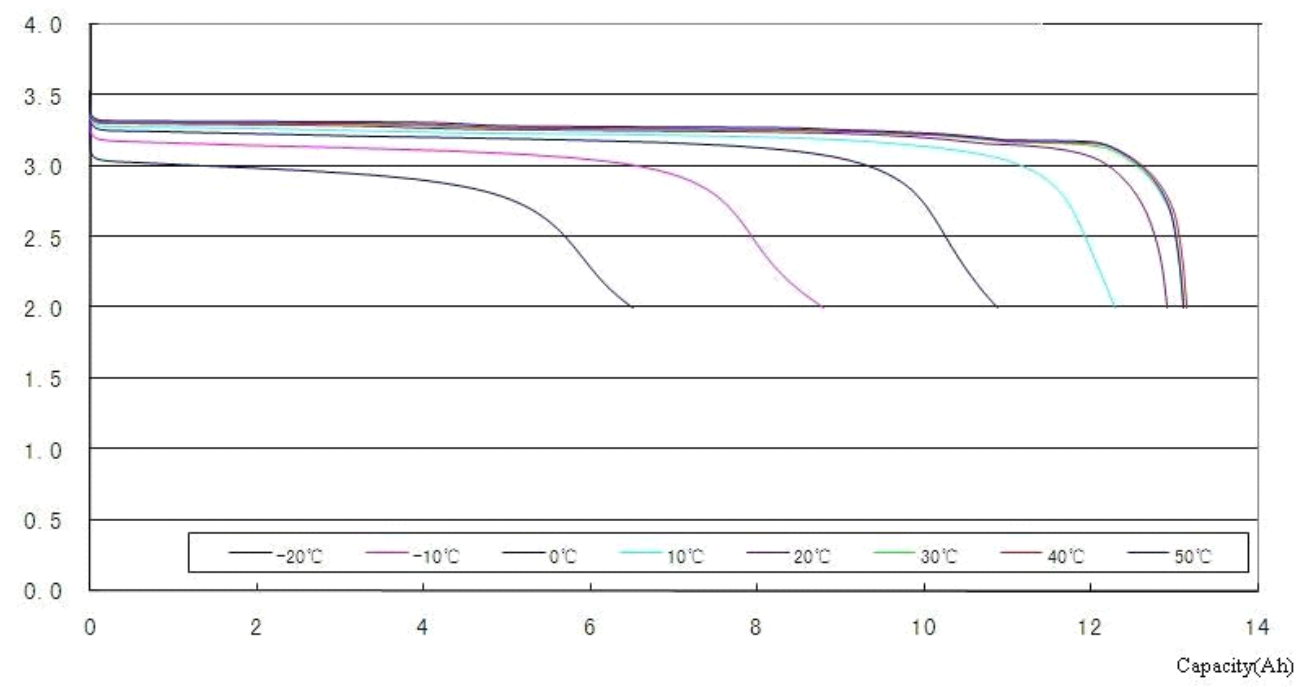

Fig. 6. Discharge characteristics for different temperature values at discharge current $0.3 \mathrm{~A}[13]$
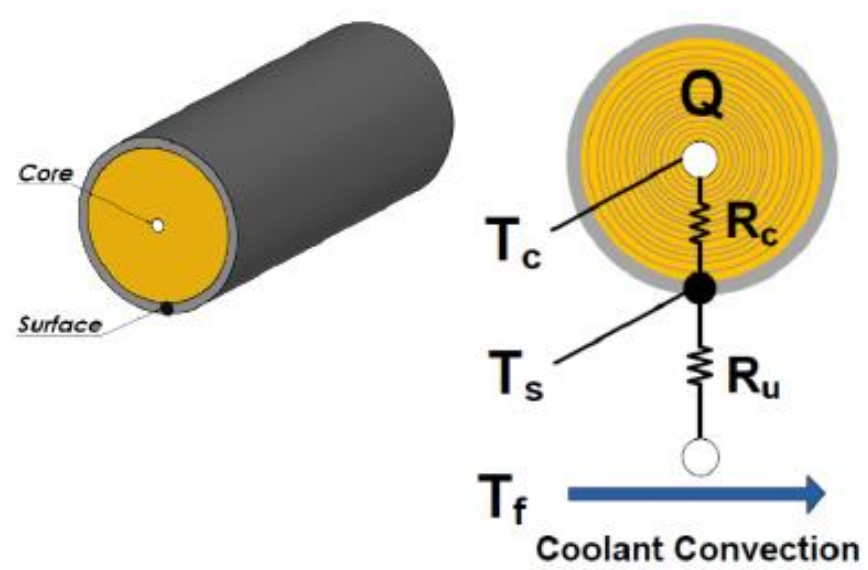

Fig. 7. Thermal model of single replacement battery cells: $T_{c}-$ core temperature; $T_{s}$ - the surface temperature; $T_{f}$ - temperature flowing coolant; $Q$ - heat; $R_{c}$ - thermal resistance between the $T_{c}$ and $T_{s} ; R_{u}$ - thermal resistance between $T_{f}$ and $T_{s}[5,6]$ 


\section{THE CONCEPT OF ENERGY MEASURING SYSTEM FOR THE UNDERWATER VEHICLE}

Due to the lack of a dedicated energy meter for the vehicle class Booby and the data contained in the characteristics (fig. 4-6), you must create a meter based on microprocessor systems, which should measure the following:

- current measurement;

- measurement of temperature (the operating temperature of battery, the operating temperature of sensors);

- voltage measurement.

\section{Current measurement}

Due to the fact that the battery capacity is measured in Ah, the most important is the measure of the current flowing at specified intervals. To this end, the sensor of power dispensed by the battery is used, which is read at specific intervals by the microprocessor.

Currently, on the vehicle deployed are 8 parallel rows of cells, which are tight fitted, so there is no possibility of measuring the currents drained from each cell.

In order to estimate the values of current retrieved from a cell, the simulation of vehicle operation was carried out [4]. It is shown for a constant, given vehicle speed of $2.0 \mathrm{~m} / \mathrm{s}$, the swell of the direction of $90^{\circ}$ with the speed, respectively: 1) $v_{p}=0.4 \mathrm{~m} / \mathrm{s}$; 2) $v_{p}=0.6 \mathrm{~m} / \mathrm{s}$; 3) $v_{p}=0.8 \mathrm{~m} / \mathrm{s}$; 4) $v_{p}=1.0 \mathrm{~m} / \mathrm{s}$; 5$) v_{p}=1.2 \mathrm{~m} / \mathrm{s}$. The selected from [4] variant of simulation of the underwater vehicle operation (fig. 2, 3), that shown the energy consumption (converted into maximum working time) needed for the supply of the drive system on the level of $24-33 \%$, so the task acceptable to implementation. Travelled in the course of the simulation by the vehicle road was 693-777 m. On figure 8 for this variant the simulated flow of current to the drive system was presented, which in figure 9 was examined quantitatively.

By analyzing quantitatively the electric current needed for propulsion power in the simulation, it can be seen that for much part of time of the operation of the underwater vehicle current values is in range between 10-14 A. In addition, the change of course at the point of return is causing the current consumption at more than $30 \mathrm{~A}$. 


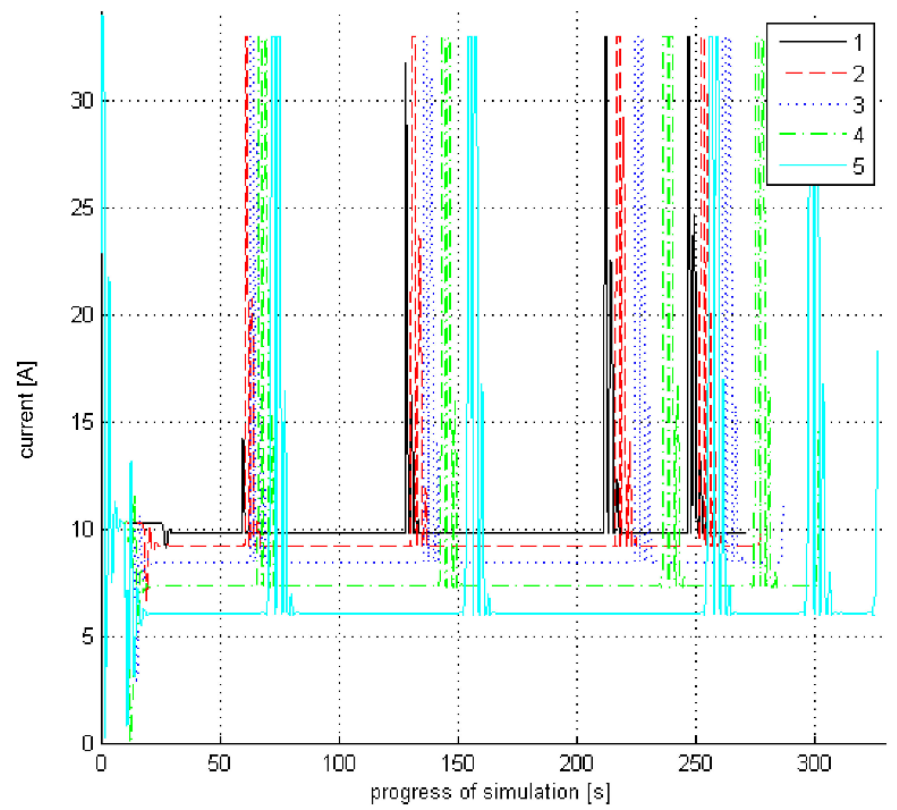

Fig. 8. The current flowing to the drive system: 1) $v_{p}=0.4 \mathrm{~m} / \mathrm{s} ; 2$ ) $\left.v_{p}=0.6 \mathrm{~m} / \mathrm{s} ; 3\right) v_{p}=0.8 \mathrm{~m} / \mathrm{s}$; 4) $v_{p}=1.0 \mathrm{~m} / \mathrm{s}$; 5) $v_{p}=1.2 \mathrm{~m} / \mathrm{s}$ [own study]

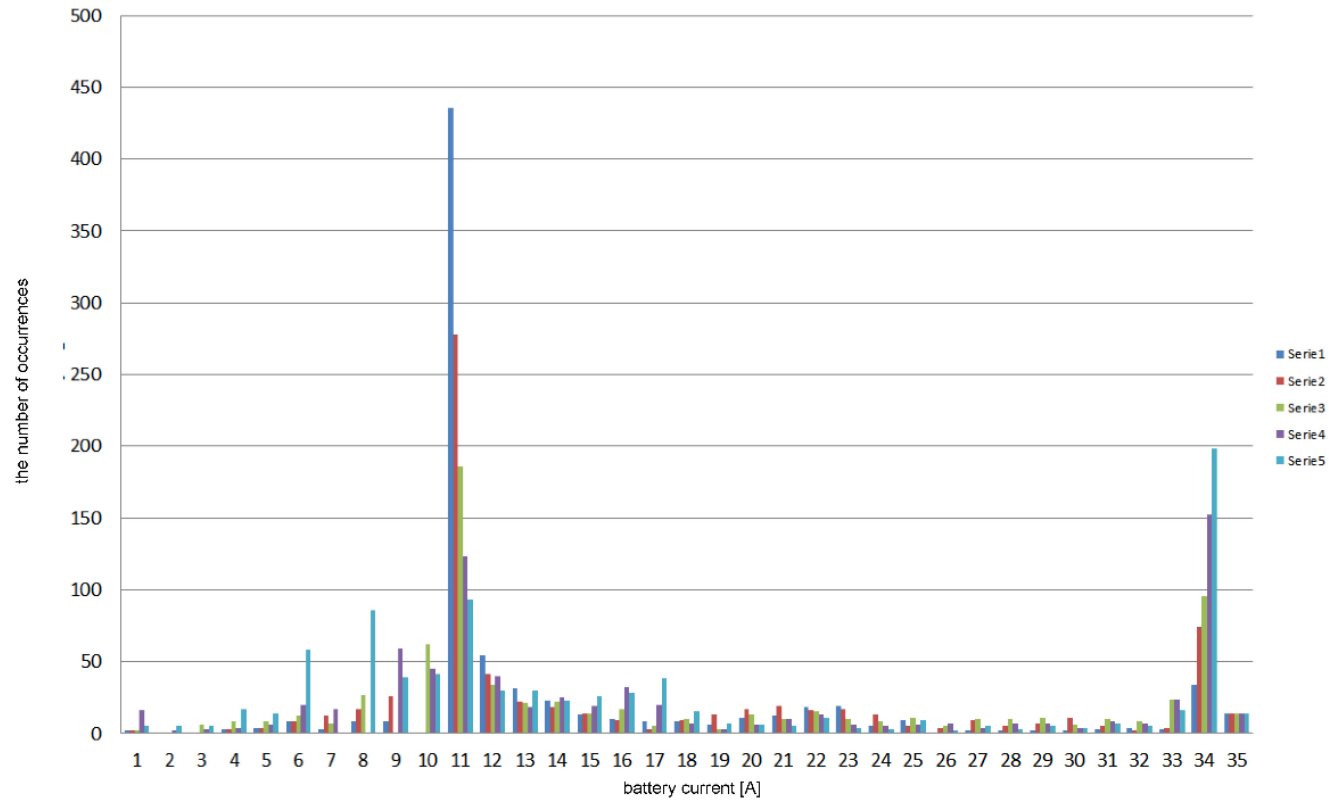

Fig. 9. The analysis of current flowing from the battery - with different values of the marine current speed: 1) $v_{p}=0.4 \mathrm{~m} / \mathrm{s}$; 2) $v_{p}=0.6 \mathrm{~m} / \mathrm{s}$; 3) $v_{p}=0.8 \mathrm{~m} / \mathrm{s}$; 4) $\left.v_{p}=1.0 \mathrm{~m} / \mathrm{s} ; 5\right) v_{p}=1.2 \mathrm{~m} / \mathrm{s}$ [own study] 


\section{Temperature measurement}

Due to the fact that the currents in the system do not exceed 36A, the use of the sensor (e.g. based on the company's ACS758xCB Allegro MicroSystems [10]) current measuring to $50 \mathrm{~A}$ is recommended. The current sensor must be cooled with heat sink, due to the fact that the manufacturer says that 20 seconds measurement current of $30 \mathrm{~A}$ causes heating of the transducer to $150^{\circ} \mathrm{C}$, and as a consequence of its damage.

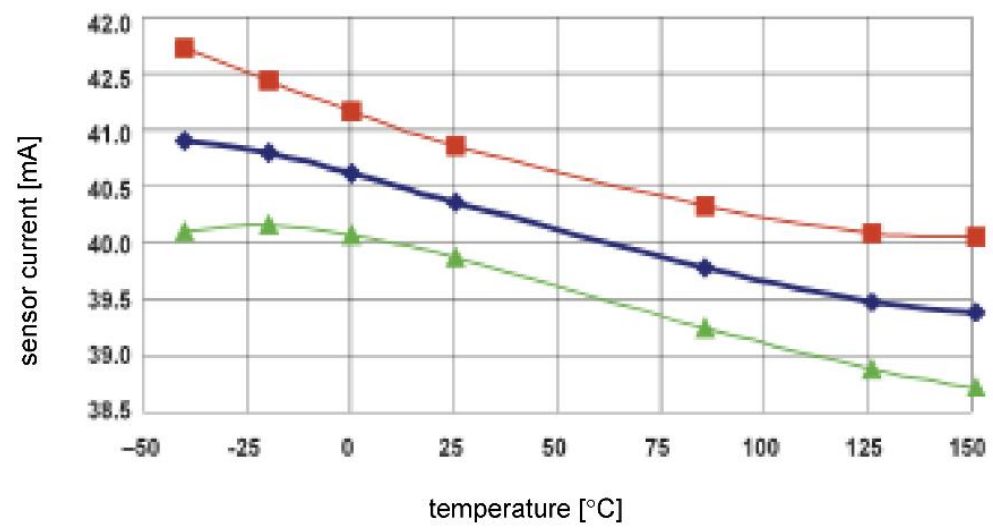

Fig. 10. The accuracy of the measurement of the sensor current depending on the temperature [10]

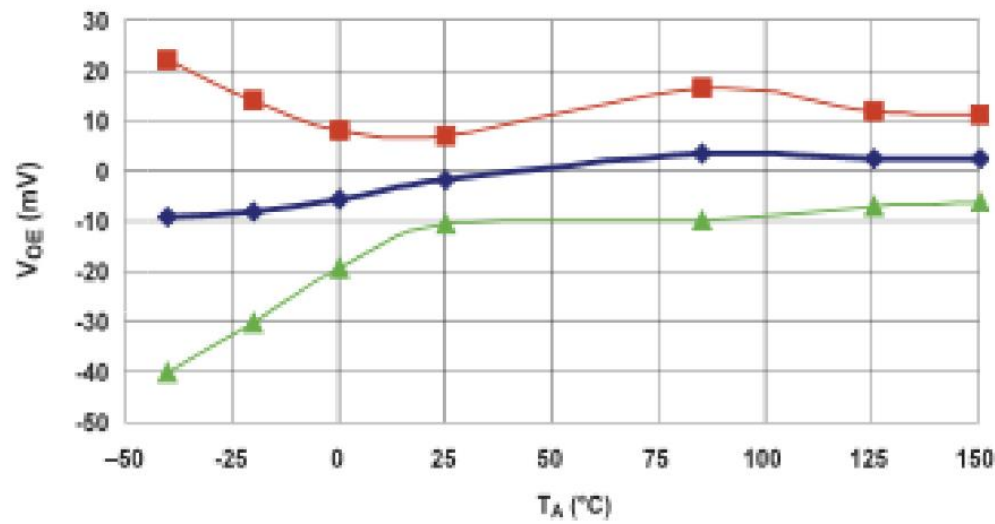

Fig. 11. The displacement of the point ' $0 A^{\prime}$ ' on the sensor depending on the temperature [10]

In addition, from the figures 10 and 11, it can be seen that it is necessary to use a temperature sensor for the determination of the correct value of current measured at a time and that way the transducer imposes the additional use of 
a suitable resolution of the A/D converter, whose accuracy affects the accuracy of the interpretation of the result by the microprocessor that analyzes the read voltage at the output of the sensor.

Basic A/D converter, which is available in microcomputer systems, is a 10-bits, i.e. $4.883 \mathrm{mV} /$ bit with sensor supply of $5 \mathrm{~V}$ - it gives the accuracy of $81 \mathrm{~mA} / \mathrm{bit}$ for direct current. The adequate accuracy can be obtained only for A/D converter with a resolution of 16 bits, which allows for accuracy of $0.067 \mathrm{mV} / \mathrm{bit}$ - this gives the possibility to read the current of $1.27 \mathrm{~mA} / \mathrm{bit}$.

In practice, it is possible to measure the current only in the every row of cells, because the measurement of $1 / 8$ power dispensed by the battery, even though more accurate, is not possible due to unavailability in the process of measuring, many higher accuracy sensors of the current flow of small values. Use 8 sensors requires use of another microprocessor system, which increases the accuracy of the measurement, and gives the ability to analyze individual rows of cells. The advantage of this solution is the lack of the need for heatsinks for the sensors, and the disadvantage is the use of more pairs of sensors: the current sensor and the temperature sensor.

The way of connecting battery cells gives the ability to use much less number of the temperature sensors than the number of cells, which will measure the current operating temperature of the power module [5].

\section{The voltage measurement}

The value of the voltage at the terminals of the battery cells is measured by the specialized microcomputer system, whose task is to measure the voltage at the terminals of the individual cells or groups of cells in the battery pack using sensors that test voltage.

To set out in detail how to measure the voltage at the terminals of the battery cells is a separate issue that needs investigations, which the effect would be the diagnosis of their condition. The operation of the meter should negligibly overload the power supply of the vehicle. Information on the voltage on the battery cells and their state is committed to the system that evaluates the current energy consumption.

Temperature sensor and current sensor in conjunction with the measurement of the voltage on the terminals of the battery support the process of estimating the remaining amount of energy in the battery module. The proposed structure of the meter gives the ability to take into account in the process of measurement of characteristics, which are supplied by the manufacturer: battery life cycle curve (fig. 4), battery 
discharge characteristics for different currents (fig. 5) and battery discharge characteristics for different temperatures (fig. 6).

\section{Layout scheme of energymeter}

Based on previous discussion, it can be specified the following diagram of the power measurement system supplied from the batteries of the underwater vehicle.

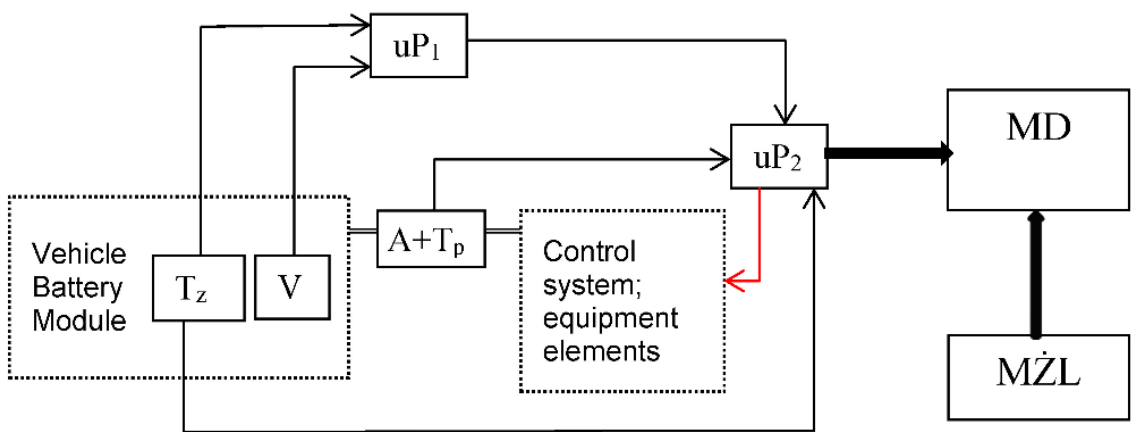

Fig. 12. A simplified layout of the system for measuring the current battery capacity: $T_{z}$ - the set of temperature sensors in the module power supply; $V$ - the set of sensors that perform voltage measurement on selected terminals of the batteries; $A+T_{p}$ - the sensor module of current flowing from the power supply integrated with the sensor of temperature emitted during the current flow; $u P_{1}-$ microprocessor system for measuring voltage and battery; $u P_{2}-$ microprocessor system estimating energy consumption; $M Z L$ - the module with a set of laser gyros; $M D$ - supervising the way of the vehicle (fig. 2) [own study]

\section{SUMMARY}

Shown in the figure 12 the wiring diagram of the microprocessor measurement meter of the amount of energy download from the battery of the underwater vehicle gives the ability to precisely determine the structure of the system controlling the expenditure of energy in the underwater vehicle.

The scheme also provides the basis for the creation of a version the system with the possibilities of diagnostics the state of the individual battery cells, and hence to obtain fuller information about the possibility of the execution of a task.

From the figure 9 it can be seen that it might be necessary to modify the control system, in such a way that the percentage of high power consumption by the propulsion system is reduced to a minimum. This is possible by increasing the amount 
of return points while reducing the angle of return and (what will be the most important) more precise circumscribing position relative to a given route and its adjustment. However, it is possible only after the change of the precision of the determination of the position of the vehicle, and checking how after the change of the accuracy the underwater vehicle responds to change of environmental conditions.

\section{REFERENCES}

[1] Fossen T. I., Fjellstad O. E., Nonlinear modelling of marine vehicle in 6 degrees of freedom, 'Journal of Mathematical Modelling of Systems', 1995, No. 1, pp. 17-28.

[2] Fossen T. I., Guidance and Control of Ocean Vehicles, John Wiley \& Sons Ltd., 1994.

[3] Garus J., Dynamika i sterowanie bezzałogowego statku głębinowego, 'Zeszyty Naukowe Akademii Marynarki Wojennej' [Scientific Journal of Polish Naval Academy], 2005, No. 162 A [Dynamics and control of unmanned deep water vehicle - available in Polish].

[4] Leszczyński T., The effect of interference parameters on the exploitation capabilities of an underwater vehicle, 'Zeszyty Naukowe Akademii Marynarki Wojennej' [Scientific Journal of Polish Naval Academy], 2016, No. 3, pp. 85-106.

[5] Lin X., Fu H. et al., Parameterization and Observability Analysis of Scalable Battery Clusters for Onboard Thermal Management, 'Oil \& Gas Science and Technology', 2013, Vol. 68, No. 1, pp. 165-178.

[6] Perez H. E., Ding Y. et al., Parameterization and Validation of an Integrated Electro-thermal Cylindrical LFP Battery Model, ASME 2012 5th Annual Dynamic Systems and Control Conference, Fort Lauderdale 2012.

[7] Rowiński L., Opis rozwiq̨zań technicznych analizowanych dla samobieżnego ładunku niszczqcego, report on research work, Gdańsk University of Technology, Gdańsk 2002 [Description of technical solutions analyzed for Self-Propelled Destructive Cargo — available in Polish].

[8] Department of Ship Design and Subsea Robotics, Gdańsk University of Technology, [online], www.underwater.pg.gda.pl [access 04.08.2017].

[9] Hydrodynamic forecasts of the Baltic Sea from the HIROMB model, [online], http://baltyk. pogodynka.pl/ftp/hiromb/hiromb/index.html [access 04.08.2017].

[10] ACS758. Datasheet, pdf, [online], https://www.allegromicro.com [access 20.04.2017].

[11] Digital Compass Solution HMR3000. Datasheet, pdf, [online], https://aerocontent.honeywell. com [access 24.04.2017].

[12] GG1320AN Digital Ring Laser Gyroscope. Datasheet, pdf, [online], https://aerocontent. honeywell.com [access 11.02.2015].

[13] Headway LiFePo4. Datasheet, pdf, [online], www.akkuenergiesysteme.de [access 13.05.2016]. 


\section{KONCEPCJA MIKROPROCESOROWEGOUKŁADU REJESTRACJI ZUŻYCIA ENERGII W POJEŹDZIE PODWODNYM}

\section{STRESZCZENIE}

W artykule, wykorzystując pojazd podwodny „Głuptak” przeznaczony do zwalczania min, przedstawiono ogólną koncepcję mikroprocesorowego układu rejestracji zmian energii elektrycznej zgromadzonej w akumulatorach pojazdu podwodnego w czasie realizacji postawionego zadania. System rejestracji ilości energii pozwala na optymalizację realizacji czasu pracy systemu napędowego pojazdu podwodnego $\mathrm{w}$ warunkach działania zakłóceń typu podwodnego prądu morskiego.

Słowa kluczowe:

pojazd podwodny, pomiar zużycia energii, położenie pojazdu.

Article history

Received: 25.09.2017

Reviewed: 04.12.2017

Revised: $\quad 14.12 .2017$

Accepted: 15.12.2017 